\title{
A Narrative Analysis of Lessing's The Fifth Child
}

\author{
Kun Zhao \\ Shandong University of Finance and Economics, China \\ Email: sjqj@163.com
}

\begin{abstract}
This paper does a narrative study on Doris Lessing's The Fifth Child for a better understanding of its narrative structure. It analyzes the narrator in the novel from overt and reliable narrative viewpoint. This paper explores the narrative power of the novel from the analysis of its narrator and narrative structure. Through the narrative skills Lessing successfully enforces the narrative power in the novel.
\end{abstract}

Index Terms - narrator, person, overt and covert narrator, reliable and unreliable narrator, point of view

\section{INTRODUCTION OF DORIS LESSING AND THE FIFTH CHILD}

Doris Lessing was born in to British parents on October 22, 1919, in Kermanshah, Iran, where her father was a captain in the British Army. Her father ended his military service when she was five years old and in 1924 the family moved to a farm in Southern Rhodesia in South Africa, where they stayed for twenty years. Doris's education began at a convent school and later at a government school for girls. Her formal education ended when she was twelve. After two failed marriages, she moved to London. She published her first novel, The Grass is Singing, in 1950. The book explores the complacency and shallowness of white colonial society in Southern Africa and established Lessing as a talented young novelist.

She is now widely regarded as one of the most important post-war writers in English. Her novels, short stories and essays have focused on a wide range of twentieth century issues and concerns, from the politics of race that she confronted in her early novels set in Africa, to the politics of gender which lead to her adoption by the feminist movement, to the role of the family and the individual in society. Doris Lessing is very much of writer of her time, deeply involved in the changing patterns of thought and culture in the western world during the last thirty years. There is great continuity between her life and her work. Her keenest interest is in the relationship between the black and white races in Africa, changing ways between generations, and the position of women in society. She stands for social justice and she believes that women should play a bigger part in improving the society by her influence, bringing less competitive aggression and higher level of culture and understanding.

Out of her numerous works, I want to choose one of her novels, The Fifth child, as the basis of this discussion. In the story, Lessing describes the changes in the happy life of a married couple, Harriet and David Lovatt, which occur as consequence of the birth of Ben, their fifth child. The novel tackles a variety of themes encompassing childhood development, the nuclear family, the difficulties of pregnancy, and the treatment of disabled children. With The Fifth Child Doris Lessing triumphs in a realm of fiction new to her. She has written an ominously tangible novel, a powerfully simple contemporary horror story that makes compulsive reading to the last word.

Though The Fifth child was not as famous as The Grass Is Singing and The Golden Notebook, her masterpieces, Doris Lessing paid so much attention to it that she wrote its sequel, Ben, in the World, after 12 years in 2000. That was unusual in the writer's life. Much analysis focuses on Doris Lessing's feminism, considered her as a feminism icon (Li, 2000), and only a few critics studied her writing style, and still fewer scholars studied her narrative characteristics. In this paper, I will analyze the narrative characteristics of The Fifth Child so that we can have a better understanding of the literature tycoon. This paper mainly focuses on the narrative structure of the novel.

\section{THE NARRATOR}

Any narrative text is related to the reader by at least one narrator who serves as the bridge between the reader and the events through his emphasis on certain characters and events through his manipulation of imagination and language (Tan, 2003). To some degree we can say that without the narrator, a narrative text may not exist, or the narrator is indispensable to a narrative text. In The Fifth Child, the narrator's type may be confusing to an inexperienced reader because the past tense and present tense are occasionally used. The narrator is discussed in two aspects: voice and point of view, for the sake of discussion of details in The Fifth Child.

\section{A. Voice}

Voice in narration is question of "who it is" we "hear" doing the narrating. Here we had better have a brief review of narrators in narratological studies to study the voice in the narrative. Much efforts has been made to separate narrators in narrative fictions into different kinds according to different criteria. Traditionally, narrators are classified into three types according to the "person", that is, first-person narrator, third-person narrator and seldom-used second-person narrator. According to the narrator's position in relation to the story he tells and extent of his participation in the events, 
there are heterodiegetic/non-character narrator and homodiegetic/character narrator; according to degree to which the narrator can be sensed, there are overt narrator and covert narrator; according to the relationship between the narrator and the implied author, there are reliable narrator and unreliable narrator.

\section{B. Person}

In the beginning, critics divided narrators into three types according to the "person": first-person narrator, third-person narrator and seldom-used second person narrator. When a narrator is a character in the story who uses the first person ( $I$ or sometimes we) to tell the event, he is a first-person narrator, just like the boy in James Joyce's Araby. Third-person narrators fall into three categories, namely, objective narrator, limited omniscient narrator and omniscient narrator.

An objective narrator tells a story from an objective point of view while he remains entirely outside of the character's mind. With objective narrator, events unfold the way they would in a play or movie. Objective narrators tell the story only by presenting dialogue and recounting events; they do not reveal the characters' thoughts or attitude. Thus, they allow readers to interpret the actions of the characters without any interference. This kind of narrator usually seems to be distant and emotionless; his perceptive is consistent with the writer's purpose in the fiction.

A limited omniscient narrator focuses only on what a single character experiences. In other words, events are limited to one character's perspective, and nothing is revealed that the character does not see, hear, feel or think. Limited omniscient narrators have certain advantages over first-person narrators. When a writer uses a first-person narrator, the narrator's personality and speech color the story, creating a personal even an idiosyncratic narrative. Also the first-person narrator's character flaws or lack of knowledge may limit his awareness of the importance of the event. Limited omniscient narrators are more flexible: they take readers into the mind of a particular character's mind just as a first-person narrator does, but without he first-person narrator's subjectivity, self-deception or naiveté.

An omniscient narrator moves at will from one character to another. He can present a more inclusive overview of events and characters than a first-person narrators can. Because he is not a character in the story, his perception is not limited to what any one character can observe or comprehend. An omniscient narrator can convey his attitude toward the subjective matter. Occasionally, omniscient narrators move not only in and out of the minds of characters but also in and out of a persona representing the voice of the writer that speaks directly to readers. To a large degree, the narrator in The Fifth Child belongs to this type.

The narrator in The Fifth Child moves freely among characters, both on their actions and minds. So he is an omniscient narrator. The beginning of the story, "Harriet and David met each other at an office party, neither had particularly wanted to go to, and both knew at once this was what they had been waiting for" (Lessing, 1988, p.1), shows that the narrator is a third person who can tell the readers both the event that the characters met at an office party and the mental activities of the characters that both the woman and the man had the feeling of love at the first sight. He has the capability to make his comment on the characters: conservative, old-fashioned, not to say obsolescent. He presents the suffering of Harriet with the fifth pregnancy as,

When she at last lay down, regulating her breath, she would start up again, with an exclamation, and, knowing he was awake, would go downstairs to the big family room where she could stride up and down groaning, swearing, weeping, without being observed". She imagined pathetic botched creatures, horribly real to her, the products of a Great Dane or a borzoi with little spaniel; a lion and a dog; a great cart horse and a little donkey; a tiger and a goat (Lessing, 1988, p. 39-41).

In these quotations the events and the minds of the character are presented one after another, sometimes even in the same sentence. The narrator knows all before the readers and he leads the readers to explore all events and the characters' minds.

In summary, grammatical person is all important feature of voice in narration, but more important is the kind of character or non-character in the narrative. It is whose voice that colors the story.

\section{Overt Narrator and Covert Narrator}

The concept of overt narrator and covert narrator were first put forward by Seymour Chatman in 1978 in his Story and Discourse. An overt narrator may be a character in the story or a narrator intruding from outside the story. He usually has a strong subject consciousness to address to readers directly or indirectly in the first person $I$ or $w e$. While a covert narrator appears in concealing narration in which the reader can hear the voice narrating the events, the characters and the scenes but the holder of the voice remains in the shadow. A covert narrator presents the events and with the least intervention by allowing the events to develop its own logic and letting the characters play their roles in their own reasonable ways. He tries not to contact the reader, not to influence the reader's judgment on characters and events, and not to show his own attitude as well. The narrators in Lessing's Wine as well as in Hemingway's Hills Like White Elephants belong to this type, so much so that, the readers can hardly notice the existence of the narrator.

The narrator in The Fifth Child is an overt narrator since he often indirectly addresses the reader while intruding from outside the story. The reader can notice the existence of the narrator in the events he described. For example, "His real father married one of his kind: she was a noisy, kind, competent woman, with the cynical good humor of the rich" (Lessing, 1988, p. 7). When a narrator narrates an event, he not only gives the readers the fact but also his attitude. The narrator's attitude towards David's step-mother (Jessica) is obviously not friendly. He influences the readers with his 
strong attitudes from beginning to the end.

\section{Reliable Narrator and Unreliable Narrator}

The concepts of reliable and unreliable narrators were brought forward by Wayne Booth in his The Rhetoric of Fiction (1983). He points out the reliable author is someone "when he speaks for or acts in accordance with the norms of the work (which is to say, the implied author's norm), unreliable when he does not" (Booth, 1983, p.159). The implied author refers to the image of the writer constructed by the reader from the text, which may be different from the real author who created the text. As the writer's second self, the implied author would have some connection with the real author. In judging the reliability of the narrator, what is important lies in whether his norms are in accordance with the implied author's norms or not. Unreliability does not mean that the narrator is lying on his description of the characters and events, in the more often seen cases; the narrator is estranged from the implied author due to his "prejudice" against the characters or events for one reason or another. The unreliable author may be distant to different extent from the implied author morally, intellectually, physically. Whereas the reliable narrator serves as a good guide leading the readers through the event and usually represents the implied author's norms. Normally, the readers tend to accept the norms presented by a reliable narrator. The narrator of The Fifth Child is presenting the events with the implied author's norms. The implied author explores the idea of perfection in reality if it is achievable. He paints a negative picture of the Lovatts' from the very beginning of the novel and continues to do so throughout its entirety. "Harriet and David met each other at an office party neither had particularly wanted to go to, and both knew at once that this is what they had been waiting for"(Lessing, 1988, p.1). The characters here are not the same as heir peers. They are unrealistic to the society and they want the perfection on everything they involve. Throughout the novel Harriet and David discover the dangers of perfection in the face of an imperfect world. In the beginning of the novel the implied author shows Harriet and David successfully construct the perfect life they both dreamt of ---- an "old-fashioned" life centered on togetherness, family, and contentment. However, the perfect life they attempted to create is in severe contrast to the reality of the world that goes on outside their home. As this external reality becomes a part of their every day life, their dreams of perfection seem futile and unachievable. In the end, the perfect world they attempted to establish is lost completely in the darkness of a flawed world. The implied narrator here is represented by a reliable narrator.

The narrator adds further imperfection to the lives of Harriet and David during an otherwise perfect family Christmas, "a cloud...Sarah and her husband, William were unhappily married, and quarreled and made up, but she was pregnant with her fourth, and a divorce was impossible" (Lessing 1988, p.20-21). The reliable narrator puts a further ominous cloud when Sarah's baby is not a perfect baby but rather is affected by Downs Syndrome. Harriet remarks to David, foreshadowing future events, that "Sarah and William's unhappiness, their quarrelling, had probably attracted the Mongol child" (Lessing 1988, p.22). This statement of Harriet is well placed by the implied author. It causes the reader begin to think of the possible outcomes of the Lovatts' selfish desire for perfection.

Harriet's pregnancy with Ben is insufferable, and her misery dampens the spirit of the house, which cannot handle "tears and misery". "The quietly insistent patient quality that had brought them together...this demand on life, which had been met in the past with respect (grudging or generous), was now showing its reverse side, in Harriet lying pale and unsociable on her bed" (Lessing 1988, p.37). A division in the family begins to show itself because of Harriet's pain, which is so bad that she takes massive amounts of tranquilizers. Harriet feels at times that she is pregnant with something evil, an "enemy" (Lessing 1988, p.40), perhaps even satanic: "Sometimes she believed hooves were cutting her tender inside flesh, sometimes claws" (Lessing 1988, p.51). Her pregnant state is symbolic of imperfection and evil growing deep within the family.

The little town they lived in had changed in the five years they had been. Brutal incidents and crimes, once shocking everyone, were now commonplace...The house next door had been burgled three times; the Lovatts' not yet, but then there were always people about...There was an ugly edge on events: more and more it seemed that two peoples lived in England, no one----enemies, hating each other who could not hear what the other said. The young Lovatts made themselves read the papers, and watch the News on television, though their instinct was to do neither. At least they ought to know what went on outside their fortress, their kingdom, in which three precious children were nurtured, and where so many people came to immerse themselves in safety, comfort, and kindness (Lessing 1988, p.22).

Thus we see that the troubled world is getting closer and closer to penetrating the Lovatts' fortress, as close as the house next door. It is shortly after this that Harriet first refers to herself as "a criminal" (Lessing 1988, p. 25), implying that she is somehow breaking the laws of society. Her crime is attempting to have a perfect life in an imperfect world. The high expectation in the imperfect world is the background put forward by the implied author's attitude, and the narrator presented it clearly with his narration. He became a reliable narrator.

From above discussion we can see the narrator in The Fifth Child is all omniscient, heterodiegetic/non-character, overt and reliable narrator. He knows every aspect of the events and moves freely from one character to another and presents the facts and ideas at the same time. He exists before the events, without personal contact with the characters, yet he makes comments from time to time, and his norms are in agreement with those of the implied author.

However, the above discussions mainly focus on the narrative voice, that is, the problem of "who says". We have to explore another problem on "who sees" to have a better understanding on the narrator of The Fifth Child in next part. 


\section{POINT OF VIEW}

Considering the narrative situation in The Fifth Child, we can find that the narrative voice comes from the heterodiegetic/non-character narrator who doesn't take part in the events at all, but careful study shows that the narrative perspective comes from the protagonist, Harriet, while the heterodiegetic author still holds his perspective to some extent. The narrator observes the characters and events from Harriet's perspective, so her thoughts, actions and the other characters' behaviors and speeches are all the objects of her focalization.

When the internal perspective is taken, the focalizer may describe the other character's appearance, but it is hard for him to describe his own. In The Fifth Child, the other character's appearances were described from Harriet's point of view. Except at the begging, we seldom read the direct description on Harriet's appearance. David's "serious blue eyes taking their time over...to Harriet he did not have someone solidly planted" (Lessing, 1988, p.4). When Ben was born, Harriet studied him carefully. "He was not pretty baby. He did not like a baby at all" (Lessing, 1988, p.48). She focused on the baby's look, hair, hands and especially, his eyes. "He opened his eyes and looked straight up into his mother's face. They were focused greeny-yellow eyes, like lumps of soapstone" (ibid: 49). Harriet "was about to go around to the back when the door abruptly opened to show a slatternly girl wearing jerseys, cardigans, and a thick scarf' (Lessing, 1988, p. 78).

The writer also observes other character's actions in Harriet's eyes. Here are some examples:

1) One day, she ran a mile or more after him (Ben), seeing only that stubby squat little figure going through traffic lights, ignoring cars that hooted and people who screamed warnings at him. (Lessing, 1988, p. 63)

2) Harriet saw the girl turn right and disappear, and without thinking she opened a door at her right hand. She saw the young man's arm raised in imprecation, or warning, while what was behind that door reached her.( Lessing, 1988, p. 81)

From Harriet's point of view, the narrator witnessed the events. In the first example, Harriet chased after Ben in the street. Her observation shows her worry at the child's action. The second example happened at the institution when Harriet came to visit Ben, the unexpected behavior of the nurse and the doctor and the horrible future of Ben irritated Harriet to take her child home in the end. All these description of appearance and actions implied that Harriet, a character of the novel is the focalizer of the story. Meanwhile, the heterodiegetic narrator holds some of his point view, though not frequently.

We only read the direct description on Harriet's appearance at the very beginning when she was at the party. "The focusing eyes then saw curly dark hair, which was unfashionable...blue eyes, soft but thoughtful...lips rather too firmly closed" (Lessing, 1988, p.4). The "focusing eyes" are not those of Harriet, they belong to the heterodiegetic narrator. Besides, the narrator often echoes the thought of Harriet, the focalizer, and therefore to address directly to the readers with his own point of view.

"Well?" said Harriet humorously as they got into his car to return to London. "and how are we going to pay for it all if I am pregnant?"

Quite so: how were they? Harriet indeed became pregnant on that rainy evening in their bedroom. (Lessing, 1988, p.11)

"Quite so: how were they?" is a reaction produced by the heterodiegetic narrator. Though he did not participate in the events, he made comments and questions to focus the readers attention on what he narrates. The narrator's reflections on what he saw lead the readers follow his narration. However, the story contains more than one focalizer, it is necessary to shift from one to another.

The shift of focus

The shift among focalizers is one of the characteristics of multifocalizer narrative. Let's look at an example from The Fifth Child.

A scene in the kitchen: family supper. Harriet and David commanded the head and foot of the table. Luke and Helen sat together on one side. Alice held little Paul...Jane sat near Dorothy's place, who was at the stove, ladle in her hand. Harriet looked at her mother, a large healthy woman in her fifties, with her bush of iron-grey curls, and her pink fresh face, and her large blue eyes "like lollipops"----a family joke----and thought I'm as strong as she is. I'II survive... (Lessing, 1988, p.42-43)

In this quotation, the voice comes from the heterodiegetic/non-character narrator, who narrates the event over the shoulders of the character. But the focalization has shifted from the narrator to one character, Harriet, with the expression "Harriet looked at her mother". With the point of view of the narrator, the writer presented the scene of the family dinner to readers, but introduced Dorothy's appearance from Harriet's standpoint so that Harriet's inner world was exposed.

\section{CONCLUSION}

With the above analyses we can see that Lessing was careful in choosing her narrator in The Fifth Child. On the one hand, and she turns to an omniscient, heterodiegetie/non-character overt reliable narrator to serve the function of narrating, persuading, intervening and manipulating the narrative speed; On the other hand, she attempts to shift her narrator's perspective from one of the characters, Harriet, to the narrator's own, so that she can penetrate the protagonist's inner world at will and the readers can vividly understand the process how the tragedy of the fifth child is 
formed.

The narrative structure was enforced by a perfect arrangement of its narrator. When the narrator is a heterodiegetie/non-character overt reliable one, he has enough freedom in space to jump from the exterior space (environment) to the interior space (the inner world of characters). Narrative itself is a power; the power is enforced by Doris Lessing's narrative rhetorical skills. Though she did not provide a cause and effect analysis on the process of Ben's tragedy, we can learn the causation from psychoanalysis. Because he did not get enough love and attention from his parents, Ben did not complete his psychological developments and got fixed at his anal stage. He was deprived of normal capability to communicate with others, including his family. The tragedy of Ben was caused by the pursuit of perfect happiness of the Lovatt couple.

Today Doris Lessing has been an honorable and respectable woman writer of British literature, who has received considerable critical attention both at home and abroad. Her typical novel in 1980s, The Fifth Child, is necessarily received its objective and impartial treatment it deserves. This paper explores the narrative power of the novel from the analysis of its narrator and narrative structure. It is helpful to understand the narrative power of Doris Lessing and the great English artist herself.

\section{REFERENCES}

[1] Abbot, H. Porter. (2007). The Cambridge Introduction to Narrative. Beijing: Peking University Press.

[2] Abrams, M. H. (2004). A Glossary of Literary Terms. Beijing: Foreign Language Teaching and Research Press.

[3] Bloom, Harold. (1986). Modern Critical Views: Doris Lessing. New York: Chelsea House Publishers.

[4] Booth, Wayne C. (1983). The Rhetoric of Fiction. Chicago: The University of Chicago Press.

[5] Currie, Mark. (1998). Postmodern Narrative Theory. New York: St. Martin's Press.

[6] Draine, Betsy. (1983). Substance Under Pressure: Artistic Coherence and Evolving Forms in the Novels of Doris Lessing. Madison: University of Wisconsin Press.

[7] Lessing, Doris. (1988). The Fifth Child. New York: Vintage International.

[8] Li Fuxiang \& Zhong Qinglan. (2000). Doris Lessing's Literary Creation in Eighties and Nineties. Journal of Sichuan International Studies University, 1, 58-61.

[9] Martin, Wallace. (2006). Recent Theories of Narrative. Beijing: Peking University Press.

[10] Showalter, Elaine. (2004). A Literature of Their Own. Beijing: Foreign Language Teaching and Research Press \& Princeton University Press.

[11] Stanzel, F. K. (1984). A Theory of Narrative. Cambridge: Cambridge University Press.

[12] Tan Junqiang. (2002). Narrative Theory and Aesthetic Culture. Beijing: China Social Sciences Press.

Kun Zhao, a College English teacher for non-English major students in Shandong University of Finance and Economics in Jinan, has been teaching college English for more than ten years. During this decade, she published five papers and wrote two works of American and English literature. Her research field is American and British literature. 